\title{
Article
}

\section{The Modulation of Nrf-2/HO-1 Signaling Axis by Carthamus tinctorius L. Alleviates Vascular Inflammation in Human Umbilical Vein Endothelial Cells}

\author{
Yun Jung Lee ${ }^{1,2} \mathbb{D}$, Yong Pyo Lee ${ }^{3}$, Chang Seob Seo ${ }^{4}$, Eun Sik Choi ${ }^{2}$, Byung Hyuk Han ${ }^{1,2}$, Jung Joo Yoon ${ }^{1,2}$, \\ Se Hoon Jang ${ }^{1,2}$, Chae Ghang Jeong ${ }^{5}$, Yeun Ja Mun ${ }^{2}$, Dae Gill Kang ${ }^{1,2, *}$ and Ho Sub Lee ${ }^{1,2, *}$ \\ 1 Hanbang Cardio-Renal Syndrome Research Center, Wonkwang University, 460, Iksan-daero, \\ Iksan 54538, Korea; shrons@wku.ac.kr (Y.J.L.); arum0924@naver.com (B.H.H.); mora16@naver.com (J.J.Y.); \\ wkdtpgns321@naver.com (S.H.J.) \\ 2 Professional Graduate School of Korean Medicine, College of Korean Medicine, Wonkwang University, 460, \\ Iksan-daero, Iksan 54538, Korea; dmstlr5421@gmail.com (E.S.C.); yjmun@wku.ac.kr (Y.J.M.) \\ 3 Division of Infectious Disease Diagnosis Control, Honam Regional Center for Disease Control and Prevention, \\ 103 Sangmusimin-ro, Seo-gu, Gwangju 62298, Korea; sendtosky@nate.com \\ 4 Herbal Medicine Research Division, Korea Institute of Oriental Medicine, 1672 Yuseong-daero, Yuseong-gu, \\ Daejeon 34054, Korea; csseo0914@kiom.re.kr \\ 5 North London Collegiate School Jeju, 33 Global Edu-ro, Seogwipo, Jeju 63644, Korea; nalago070@gmail.com \\ * Correspondence: dgkang@wku.ac.kr (D.G.K.); host@wku.ac.kr (H.S.L.)
}

\section{check for}

updates

Citation: Lee, Y.J.; Lee, Y.P.; Seo, C.S.; Choi, E.S.; Han, B.H.; Yoon, J.J.; Jang, S.H.; Jeong, C.G.; Mun, Y.J.; Kang, D.G.; et al. The Modulation of Nrf-2/HO-1 Signaling Axis by Carthamus tinctorius L. Alleviates Vascular Inflammation in Human Umbilical Vein Endothelial Cells. Plants 2021, 10, 2795. https:// doi.org/10.3390/plants10122795

Academic Editor: Adam Stebel

Received: 18 November 2021 Accepted: 9 December 2021 Published: 17 December 2021

Publisher's Note: MDPI stays neutral with regard to jurisdictional claims in published maps and institutional affiliations.

Copyright: (C) 2021 by the authors Licensee MDPI, Basel, Switzerland. This article is an open access article distributed under the terms and conditions of the Creative Commons Attribution (CC BY) license (https:// creativecommons.org/licenses/by/ $4.0 /)$.

\begin{abstract}
Carthamus tinctorius L., known as safflower, has been used in traditional treatment for cardiovascular, cerebrovascular, and diabetic vascular complications. We proposed to investigate how the ethanol extract of Carthamus tinctorius L. (ECT) can be used ethnopharmacologically and alleviate vascular inflammatory processes under cytokine stimulation in human vascular endothelial cells. Using the optimized HPLC method, six markers were simultaneously analyzed for quality control of ECT. Pretreatment with ECT $(10-100 \mu \mathrm{g} / \mathrm{mL})$ significantly reduced the increase of leukocyte adhesion to HUVEC by TNF- $\alpha$ in a dose-dependent manner. Cell adhesion molecules (CAMs) such as intracellular adhesion molecule-1 (ICAM-1), vascular cell adhesion molecule-1 (VCAM-1), and endothelial cell selectin (E-selectin) are decreased by ECT. In addition, ECT significantly suppressed TNF- $\alpha$-induced oxidative stress referring to reactive oxygen species (ROS) production. p65 NF- $\mathrm{B}$ nuclear translocation and its activation were inhibited by ECT. Furthermore, pretreatment of ECT increased the HO-1 expression, and nuclear translocation of Nrf-2. These data suggest the potential role of ECT as a beneficial therapeutic herb in vascular inflammation via ROS/NF-kB pathway and the regulation of Nrf-2/HO-1 signaling axis is involved in its vascular protection. Thus, further study will be needed to clarify which compound is dominant for protection of vascular diseases.
\end{abstract}

Keywords: Carthamus tinctorius; HUVEC; vascular inflammation; HO-1; Nrf-2; NF-кB

\section{Introduction}

Atherosclerotic cardiovascular disease is the leading cause of death globally according to a report of published by Statistics WTO, and cerebrovascular disease and cardiovascular disease were the major causes of mortality. Atherosclerosis is a pathologic process caused by oxidative stress, chronic vascular dysfunction, and vascular inflammation. Once vascular endothelium is activated, leukocytes attach to vascular endothelium, subsequently migrate into the vessel wall. Infiltrated leukocytes can be differentiated into macrophages and release tumor necrosis factor- $\alpha(\mathrm{TNF}-\alpha)$ and consequently crucial risk factor for atherosclerosis because inflammation is closely regulated by signaling processes in vessel [1,2]. In endothelium, cell adhesion molecules play crucial roles in these events. Intracellular adhesion molecule-1 (CD54, ICAM-1) is an 85-110 kDa integral membrane glycoprotein. Vascular cell adhesion molecule-1 (VCAM-1, CD106), 110 kDa transmembrane glycoprotein, is constitutively expressed in vascular endothelial cells and upregulated by cytokine 
stimulation [3,4]. Furthermore, chemokines such as monocyte chemoattractant protein-1 (MCP-1) have been reported to stimulate non-leukocytes to secrete cytokines and CAMs [5]. Intracellular reactive oxygen species (ROS) play crucial roles in several physiological processes; they impair proteins, lipids, and DNA by inducing oxidative stress due to their highly reactive nature [6]. Vascular cytokines induce the production of ROS and activate redox signaling pathways, resulting in atherosclerosis [7]. They also stimulate p65 nuclear factor- $\kappa B(\mathrm{NF}-\kappa \mathrm{B})$, a transcription factor of pro-inflammatory genes, such as CAMs [8].

Heme oxygenase-1 (HMOX1, HO-1) is a target gene of nuclear factor erythroid 2related factor 2 (Nrf2), which has been shown to protect against a variety of pathologies including sepsis, hypertension, and atherosclerosis [9]. HO-1 is further responsible for catalyzing the disintegration of heme into the antioxidant biliverdin, which is an antiinflammatory agent, carbon monoxide, and iron [10]. Metabolites such as ferric iron, CO, and bilirubin are known to have antioxidative, anti-inflammatory, and anti-atherogenic properties [11]. The HO-1 deficiency model is related to endothelial cell injury, weakness, stress, ischemia, and growth retardation. In contrast, experimental HO-1 gene delivery has been shown to alleviate atherosclerosis [12], vascular neointima formation [13], ischemic heart injury [14], and vascular dysfunction [15].

Carthamus tinctorius L. (known as Safflower) belongs to the Compositae family and is distributed in South Asia, China, Iran, and Egypt [16,17]. The flowers of C. tinctorius are traditionally used to treat cardiovascular, cerebrovascular, gynecological, and diabetic vascular complications [18]. It is regarded to have beneficial coagulant and antioxidative effects, as well as beneficial effects against cancer and cardiovascular disease [19]. However, the specific effect of $C$. tinctorius flowers on the inhibition of vascular inflammation remains unclear. In the present study, we tested the hypothesis that the ethanol extract of the flowers of $C$. tinctorius (ECT) could decrease the levels of vascular inflammation markers in response to $\mathrm{TNF}-\alpha$, upregulate $\mathrm{HO}-1$, and thus, protect against atherosclerosis. Therefore, the present study aimed to confirm the anti-vascular inflammatory effect of ECT and the molecular mechanisms underlying its action in human umbilical vein endothelial cells (HUVECs).

\section{Materials and Methods}

\subsection{Preparation of ECT}

Flowers of C. tinctorius L. (Compositae) were obtained from the Herbal Medicine Cooperative Association (Iksan, Korea) in 2018 and specimen voucher number was HBN321-01. The dried flowers of $C$. tinctorius ( $200 \mathrm{~g}$ ) was soaked in $2 \mathrm{~L}$ ethanol at room temperature for 7 days, then concentrated using a rotary evaporator (Eyela, Tokyo, Japan). The concentrated extract (50 g) was lyophilized using a freeze-drier (PVTFD10RS, IlShinBioBase, Yangju, Korea) and dissolved in dimethyl sulfoxide (DMSO, $<0.1 \%$ ) for experiments.

\subsection{Chemicals and Reagents for HPLC Analysis}

Four flavonoids, kaempferol 3-glucoside (C21H20O11, MW 448.38, purity 99.5\%, Cat No. DR10611) and kaempferol 3-rutinoside (C27H30O15, MW 594.52, purity 98.2\%, Cat No. DR11211) were purchased from Shanghai Sunny Biotech (Shanghai, China), and quercetin 3-glucoside (C21H20O12, MW 464.09, purity 98.2\%, Cat No. CFN98753) was purchased from ChemFaces Biochemicals (Wuhan, China), and quercetin 3-rutinoside (C27H30O16, MW 610.517, purity 97.2\%, Cat No. PHL89270) was purchased from Merck (Darmstadt, Germany). One miscellaneous, bidenoside C (C16H22O6, MW 310.4, Cat No. purity 99.8\%, CFN95266) and one chalcones, hydroxysafflor yellow A (C9H10O5, MW 612.5, purity 99.7\%, Cat No. CFN99950) were obtained from ChemFaces Biochemicals (Wuhan, China). Figure 1 illustrates the chemical structures of these reference standard compounds. High-performance liquid chromatography (HPLC)-grade solvents (methanol, acetonitrile, and water) and reagent, formic acid ( $\geq 99.7 \%$ ) for HPLC qualitative/quantitative analysis were obtained from J. T. Baker (Phillipsburg, NJ, USA) and Thermo Fisher Scientific (San Jose, CA, USA), respectively. 


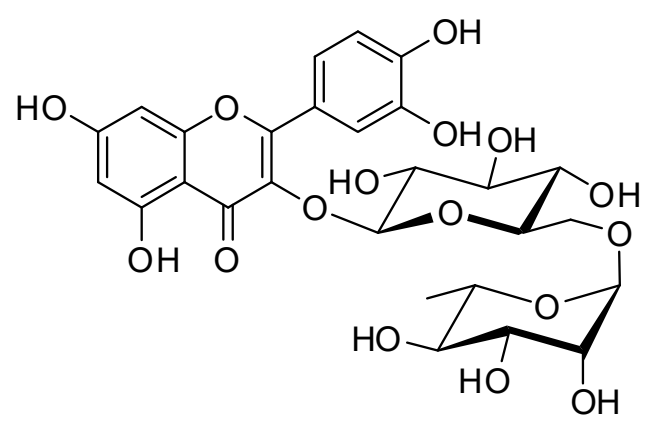

Quercetin 3-rutinoside

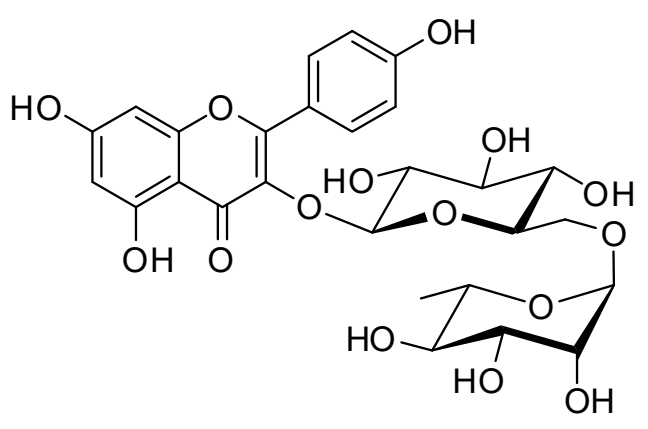

Kaempferol 3-rutinoside<smiles>O=c1c(OC(O)C(O)C(O)C(O)O)c(-c2ccc(O)cc2)oc2cc(O)cc(O)c12</smiles>

Kaempferol 3-glycoside<smiles>O=c1c(OC(O)C(O)C(O)C(O)C(O)CO)c(-c2ccc(O)c(O)c2)oc2cc(O)cc(O)c12</smiles>

Quercetin 3-glycoside<smiles>O=C(/C=C/c1ccc(O)cc1)C1=C(O)C(C2OC(CO)C(O)C(O)C(O)C2O)=C(O)C(O)(C(O)C(O)CCOC2COCC2O)C1=O</smiles>

Hydroxysafflor yellow A

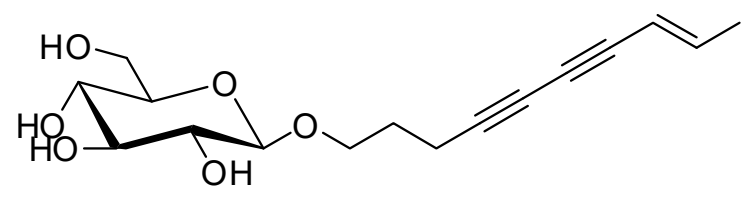

Bidenoside C

Figure 1. Chemical structures of six marker compounds in flowers of $C$. tinctorius. Four flavonoids, kaempferol 3-glucoside, kaempferol 3-rutinoside, quercetin 3-glucoside, and quercetin 3-rutinoside were included. One miscellaneous, bidenoside $\mathrm{C}$, and one chalcones, hydroxysafflor yellow A were also included in flowers of $C$. tinctorius.

\subsection{HPLC Analysis of Six Marker Analytes in Flowers of C. tinctorius}

Qualitative/quantitative for quality control of flowers of $C$. tinctorius was performed using a Shimadzu Prominence LC-20A Series (Kyoto, Japan) by controlled LCSolution software (Version 1.24, SP1). The mobile phase was comprised of $0.1 \%(v / v)$ aqueous formic acid (A), and $0.1 \%(v / v)$ formic acid in acetonitrile (B), and flowed under gradient elution conditions: $0-30 \mathrm{~min}, 20-50 \% \mathrm{~B} ; 30-35 \mathrm{~min}, 50 \% \mathrm{~B}$; $35-40 \mathrm{~min}, 50-20 \% \mathrm{~B}$; and $40-50 \mathrm{~min}, 20 \%$ B. Quantification was measured at $265 \mathrm{~nm}$ for bidenoside C, $345 \mathrm{~nm}$ for kaempferol 3-rutinoside and kaempferol 3-glucoside, $355 \mathrm{~nm}$ for quercetin 3-rutinoside and quercetin 3-glucoside, and $400 \mathrm{~nm}$ for hydroxysafflor yellow A.

\subsection{Cell Cultures}

HUVEC and human monocytic leukemia HL-60 were obtained from American Type Culture Collection (ATCC; Manassas, VA, USA), and maintained at $37^{\circ} \mathrm{C}$ in a humidified $5 \%$ 
$\mathrm{CO}_{2}$ atmosphere. Culture medium of HUVEC was Endothelial cell growth medium with $20 \%$ FBS, and that of HL- 60 was RPMI 1640 with $10 \%$ FBS. All medium contained $100 \mathrm{U} / \mathrm{mL}$ penicillin, $100 \mu \mathrm{g} / \mathrm{mL}$ streptomycin. HUVECs were used between passages 4 and 5 . To obtain confluent monolayers, HUVECs were seeded at a density of $2 \times 10^{4}$ cells $/ \mathrm{cm}^{2}$, and were used $36 \mathrm{~h}$ after incubation. The medium was changed at $24 \mathrm{~h}$ after seeding cell.

\subsection{Enzyme-Linked Immunsorbent Assay}

HUVEC were probed with mouse anti-human ICAM-1 (SC-8439, Santa Cruz, CA, USA), VCAM-1 (SC-13160, Santa Cruz, CA, USA), or E-selectin (SC-14011, Santa Cruz, CA, USA), antibodies at dilution (1:1000), in 1\% BSA, in $2 \mathrm{~h}$ room temperature, after the cells were fixed by $1 \%$ paraformaldehyde. The cells were then incubated with the horseradish peroxidase-conjugated secondary antibody. Finally, a peroxidase substrate solution was added and measured at the $490 \mathrm{~nm}$ absorbance by a microplate reader (BioRad 3550, Hercules, CA, USA).

\subsection{Western Blot Analysis}

Cell lysates (protein of $40 \mu \mathrm{g}$ ) were run on 10\% SDS-polyacrylamide gel electrophoresis, subsequently transferred to nitrocellulose membrane. Blots were blocked with 5\% BSA and then exposed to the appropriate primary antibody in dilutions (1:1000) suggested from the commercial supplier. Primary antibodies were probed with horseradish peroxidase conjugated goat anti-rabbit-IgG (SC-2004, Santa Cruz, CA, USA) or anti-mouse-IgG (SC-2005, Santa Cruz, CA, USA). Visualization was performed with enhanced chemiluminescence (RPN2209, Amersham, Buckinghamshire, UK). Capturing image was achieved by ChemiDoc image analyzer (Bio-Rad, Hercules, CA, USA).

\subsection{Total mRNA Preparation and Reverse Transcription-Polymerase Chain Reaction (RT-PCR)}

Isolation of total mRNA was conducted using Trizol reagent (\#15596026, Invitrogen). cDNA synthesis was performed by reverse transcription at $37^{\circ} \mathrm{C}$ for $60 \mathrm{~min}, 94{ }^{\circ} \mathrm{C}$ for 5 min, respectively (\#EZ105S, Enzynomics, Daejeon, Korea). The specific sequences of primers are shown in Table 1 [20]. PCR pre-mix was composed of mixture of template cDNA and $50 \mathrm{nM}$ primers, reference to the manufacturer instruction (\#25161, Intron, Korea). The amplification steps were followed by 45 cycles at $94{ }^{\circ} \mathrm{C}, 20 \mathrm{~s} ; 60{ }^{\circ} \mathrm{C}, 20 \mathrm{~s} ; 72{ }^{\circ} \mathrm{C}, 30 \mathrm{~s}$. The final PCR products were determined by ChemiDoc image analyzer.

Table 1. Primers used in PCR.

\begin{tabular}{|c|c|}
\hline Gene & Primer Nucleotide Sequence \\
\hline \multirow{3}{*}{ ICAM-1 } & Forward: 5'-CTCACCCGTGTACTGGACTC-3' \\
\hline & Reverse: 5'-CGCCGG \\
\hline & AAAGCTGTAGATGG-3' \\
\hline \multirow{4}{*}{ VCAM-1 } & Forward: 5'-ATGCCTGGG \\
\hline & AAGATGGTCGTGA-3' \\
\hline & Reverse: \\
\hline & 5'-TGGAGCTGGTAGACCCTCGCTG-3' \\
\hline \multirow{2}{*}{ E-selectin } & Forward: 5'-ATCATCCTGCAACTTCACC-3' \\
\hline & Reverse: 5'-ACАССТСАССАААСССТТС-3' \\
\hline \multirow{2}{*}{ MCP-1 } & Forward: 5'-CAGCCAGATGCAATCAATGC-3' \\
\hline & Reverse: 5'-GTGGTCCATGGAATCCTGAA-3' \\
\hline \multirow{4}{*}{$\beta$-actin } & Forward: 5'-AGGGAGGCGT \\
\hline & TCACCTCAGG-3' \\
\hline & Reverse 5'-AACTCCATCACCAGGCG \\
\hline & TGGG-3' \\
\hline
\end{tabular}

\subsection{HL-60 Monocyte and HUVEC Adhesion Analysis}

HUVEC were cultured to confluence in 24-well plates. HL-60 were labeled with $10 \mu \mathrm{M}$ BCECF-AM (\#B1170, ThermoFisher, USA) at $37^{\circ} \mathrm{C}$ and added $2.5 \times 105$ cells to the 
HUVEC and then incubated for $1 \mathrm{~h}$. Non-adhesive HL-60 were removed from the plate and HL-60 attached to HUVEC were observed by fluorescence microscope (Axiovision 4, Zeiss, Germany). The fluorescent intensity was measured at 485/585 nm (F-2500, Hitachi, Tokyo, Japan). The adhesion was represented in terms of change (\%) compared with the control.

\subsection{Intracellular ROS Production Assay}

The confluent HUVEC were pretreated with ECT and incubated with $20 \mu \mathrm{M} \mathrm{CM}$ H2DCFDA (\#C6827, ThermoFisher, Waltham, MA, USA) and then treated with TNF- $\alpha$ for $6 \mathrm{~h}$. The measurement of fluorescence intensity was obtained by spectrofluorometer and captured under a fluorescence microscope.

\subsection{NF-kB Activation Assay}

The extraction of nuclear proteins from HUVEC was carried out utilizing the nuclear and cytoplasmic protein extraction kit (\#78833, ThermoFisher, Waltham, MA, USA). The levels of p65 NF- $\mathrm{kB}$ in nuclear extracts were determined by TransAM NF- $\mathrm{kB}$ kit according to the supplier's instructions (\#40096, Active Motif, Carlsbad, CA, USA).

\subsection{Immunofluorescence Microscopy}

HUVECs on Lab-Tek II chamber slides were fixed in $4 \%$ paraformaldehyde and permeabilized by $0.1 \%$ Triton X-100. Cells were probed with NF-kB p65 antibody (SC-8008, Santa Cruz, CA, USA) followed by fluorescein isothiocyanate (FITC)-labeled secondary antibody (a11001, Santa Cruz, CA, USA), and DAPI, respectively (Santa Cruz, CA, USA). The cells were finally mounted with Dako Fluorescent mounting medium (\#CS70330-2, Agilent Technologies, Santa Clara, CA, USA) onto glass slides, and analyzed under a fluorescence microscope (Axiovision 4, Zeiss, Germany).

\subsection{Statistical Analysis}

The results were displayed as mean \pm standard error (S.E.) and were analyzed using one-way ANOVA; Dunnett's test or Student's $t$-test using version 10 Sigma Plot software to determine any significant differences. $p<0.05$ was represented as statistical significance.

\section{Results}

\subsection{Quantification of Six Marker Compounds in ECT}

Using the optimized HPLC method, six marker compounds (quercetin 3-rutinoside, quercetin 3-glycoside, kaempferol 3-rutinoside, hydroxysafflor yellow A, kaempferol 3glycoside, and bidenoside C) were simultaneously analyzed for quality control of $C$. tinctorius. Retention times of these analytes were 9.47, 11.09, 11.83, 12.56, 13.88, and $21.24 \mathrm{~min}$, respectively. Linear range, regression equation, coefficient of determination (r2), limit of detection (LOD), and limit of quantification (LOQ) for verifying the appropriateness of the established method are shown in Table 2. As a result of quantifying the marker compounds in flowers of C. tinctorius using this HPLC method, it was detected as $0.02-1.59 \mathrm{mg} / \mathrm{g}$ (Table 3).

Table 2. Linear range, regression equation, $r^{2}$, LOD, and LOQ for six marker analytes $(n=3)$.

\begin{tabular}{|c|c|c|c|c|c|}
\hline Compound & $\begin{array}{c}\text { Linear Range } \\
(\mu \mathrm{g} / \mathrm{mL})\end{array}$ & $\begin{array}{l}\text { Regression Equation } \\
\quad(y=\mathbf{a} x+\mathbf{b})^{\mathrm{a}}\end{array}$ & $r^{2}$ & $\operatorname{LOD}(\mu \mathrm{g} / \mathrm{mL})^{b}$ & $\operatorname{LOQ}(\mu \mathrm{g} / \mathrm{mL})^{c}$ \\
\hline Quercetin 3-rutinoside & $0.31-20.00$ & $y=28,539.15 x+2768.62$ & 1.0000 & 0.06 & 0.18 \\
\hline Quercetin 3-glycoside & $0.31-20.00$ & $y=28,930.08 x+1776.94$ & 1.0000 & 0.04 & 0.12 \\
\hline Kaempferol 3-rutinoside & $0.78-50.00$ & $y=21,078.39 x+3828.68$ & 1.0000 & 0.14 & 0.43 \\
\hline Hydroxysafflor yellow A & $1.56-100.00$ & $y=33,781.29 x+3563.25$ & 0.9999 & 0.19 & 0.57 \\
\hline Kaempferol 3-glycoside & $0.31-20.00$ & $y=38,389.02 x+1978.30$ & 1.0000 & 0.01 & 0.02 \\
\hline Bidenoside C & $0.31-20.00$ & $y=18,983.02 x+1748.57$ & 1.0000 & 0.01 & 0.04 \\
\hline
\end{tabular}

a $y$ : peak area of compounds; $x$ : concentration of compounds. ${ }^{\mathrm{b}} \mathrm{LOD}=3.3 \times \sigma / S,{ }^{\mathrm{c}} \mathrm{LOQ}=10 \times \sigma / S(\sigma$ : the standard deviation of the $y$-intercept; $S$ : the slope of the calibration curve). 
Table 3. Amount of the six marker analytes in flowers of C. tinctorius $(n=3)$.

\begin{tabular}{cccc}
\hline Compound & \multicolumn{3}{c}{ Leaves } \\
\cline { 2 - 4 } & Mean $\mathbf{( m g / g )}$ & SD $\left(\times \mathbf{1 0}^{-\mathbf{2}}\right)$ & RSD (\%) \\
\hline Quercetin 3-rutinoside & 0.02 & 0.04 & 2.60 \\
Quercetin 3-glycoside & 0.05 & 0.06 & 1.25 \\
Kaempferol 3-rutinoside & 0.10 & 0.19 & 1.81 \\
Hydroxysafflor yellow A & 1.59 & 0.12 & 0.07 \\
Kaempferol 3-glycoside & 0.02 & 0.06 & 2.44 \\
Bidenoside C & 0.03 & 0.06 & 2.33 \\
\hline
\end{tabular}

\subsection{Effect of ECT on TNF- $\alpha$-Induced CAMs Expression in HUVEC}

In order to estimate cytotoxic effects of ECT on HUVEC, MTT assay was performed. ECT did not show cytotoxic effects up to $100 \mu \mathrm{g} / \mathrm{mL}$ ( $>90 \%$ cell viability). Therefore, $100 \mu \mathrm{g} / \mathrm{mL}$ of ECT was used as the maximum dose in the present study (data not shown).

We first determined the inhibitory effect of ECT on the CAMs expression on TNF$\alpha$-stimulated HUVEC by Western blotting and ELISA assay. Protein expression levels of ICAM-1, VCAM-1, and E-selectin were increased by TNF- $\alpha$ treatment and these effects of TNF- $\alpha$ were significantly suppressed by $10-100 \mu \mathrm{g} / \mathrm{mL}$ ECT (Figure $2 \mathrm{~A}, \mathrm{~B}$ ). In addition, mRNA expression levels of ICAM-1, VCAM-1, and E-selectin were also reduced by ECT in TNF- $\alpha$-stimulated cells (Figure 3). These data indicate that ECT can improve to proinflammation process by regulating CAMs in vascular endothelial cells.

(A)

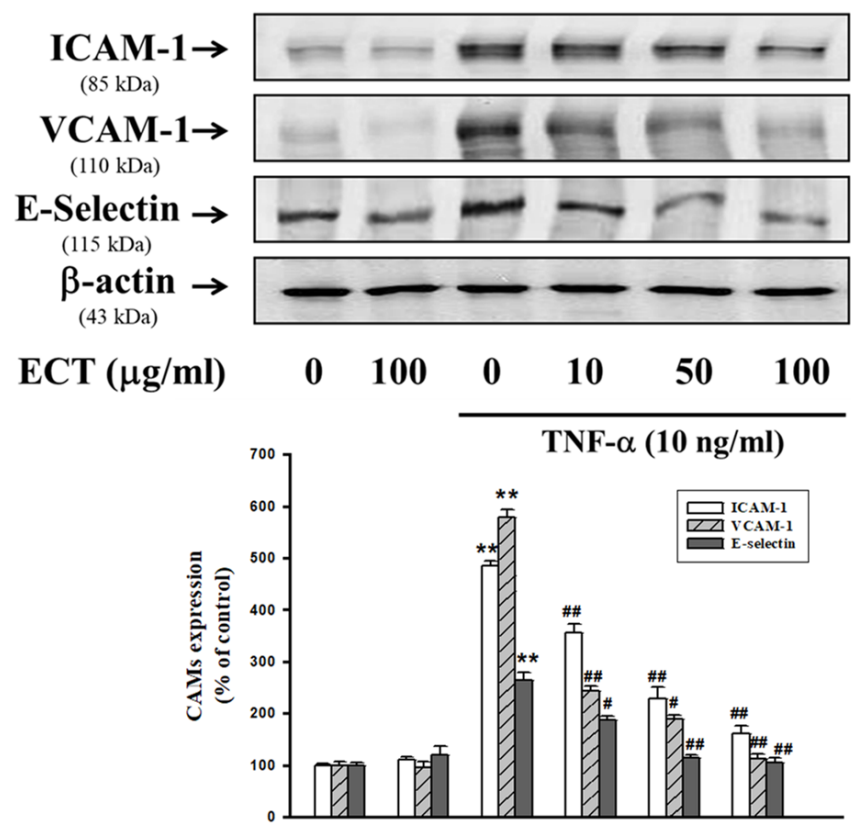

Figure 2. Cont. 


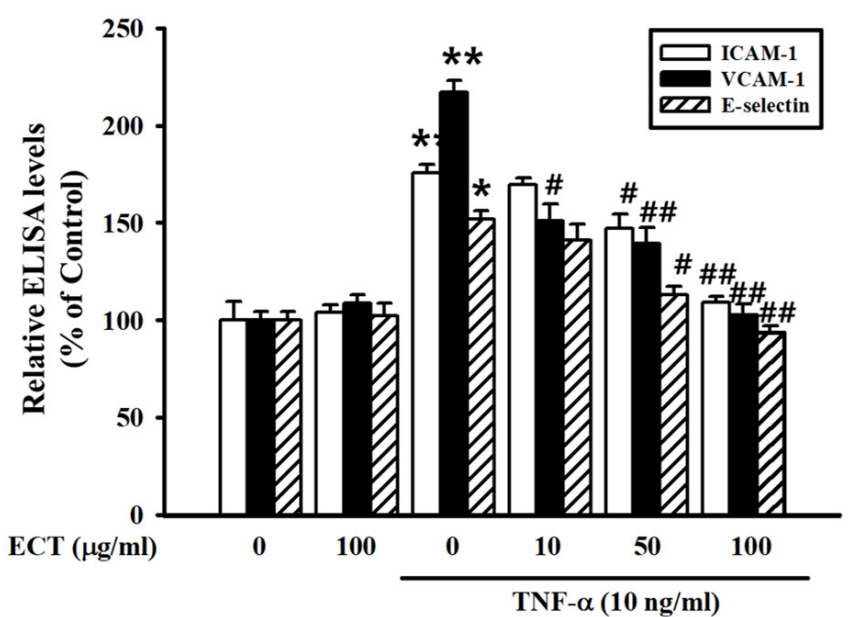

(B)

TNF- $\alpha(10 \mathrm{ng} / \mathrm{ml})$

Figure 2. Effects of ECT on TNF- $\alpha$-stimulated expression of cell adhesion molecules in HUVECs. Western blots (A) and cell surface expressions (B) of ICAM-1, VCAM-1, and E-selectin were analyzed according to Materials and Methods. Cells underwent $24 \mathrm{~h} 10 \mathrm{ng} / \mathrm{mL}$ TNF- $\alpha$ treatment in the absence or presence of $10-100 \mu \mathrm{g} / \mathrm{mL}$ ECT for $30 \mathrm{~min}$. The blots are representative of three independents. Bars indicate the means \pm SEM of three independent experiments. ${ }^{*} p<0.05$, ${ }^{* *} p<0.01$ vs. non-treated control; \# $p<0.05$, \#\# $p<0.01$ vs. TNF- $\alpha$.

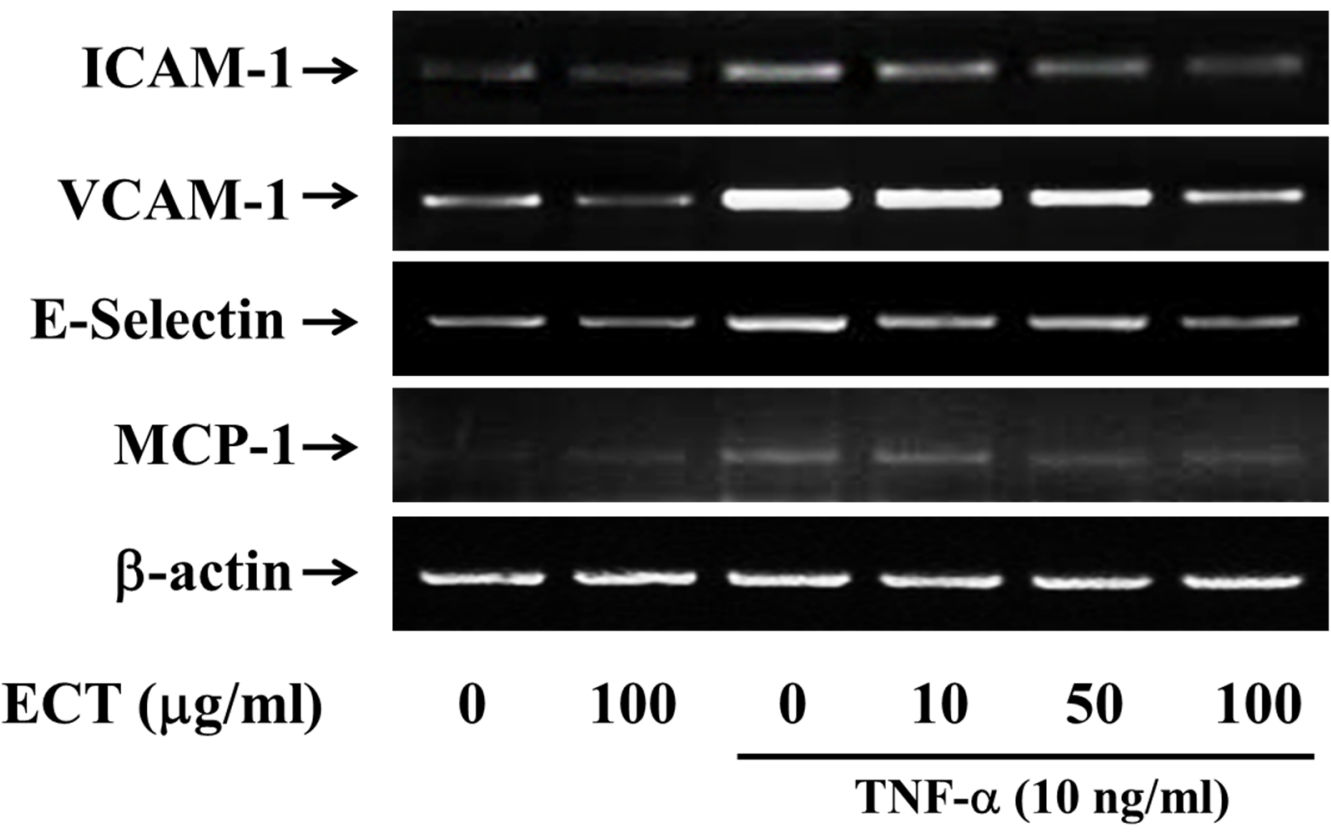

Figure 3. Effects of ECT on TNF- $\alpha$-stimulated ICAM-1, VCAM-1, E-selectin, and MCP-1 mRNA expressions. Cells were treated with $10 \mathrm{ng} / \mathrm{mL}$ TNF- $\alpha$ for $24 \mathrm{~h}$ with/without $10-100 \mu \mathrm{g} / \mathrm{mL}$ ECT for $30 \mathrm{~min}$ and then were analyzed by qRT-PCR. The blots are representative of three independents.

\subsection{Effect of ECT on Leukocyte Adhesion to Vascular Endothelial Cells}

Based on the above results, the effect of ECT on adhesion of HL-60 under cytokine stimulation was confirmed. HUVEC was pretreated with ECT (10-100 $\mu \mathrm{g} / \mathrm{mL})$, exposed to TNF- $\alpha$ and added fluorescent HL-60. As shown in Figure 4, the number of HL-60 adhesive to HUVEC was markedly increased by TNF- $\alpha$. However, pretreatment with ECT significantly reduced the adhesion of HL-60 to HUVEC in a dose-dependent manner. The untreated HUVEC showed minimal binding to HL-60. These data suggest that ECT inhibited infiltration of macrophages, found in early atherosclerotic process. 

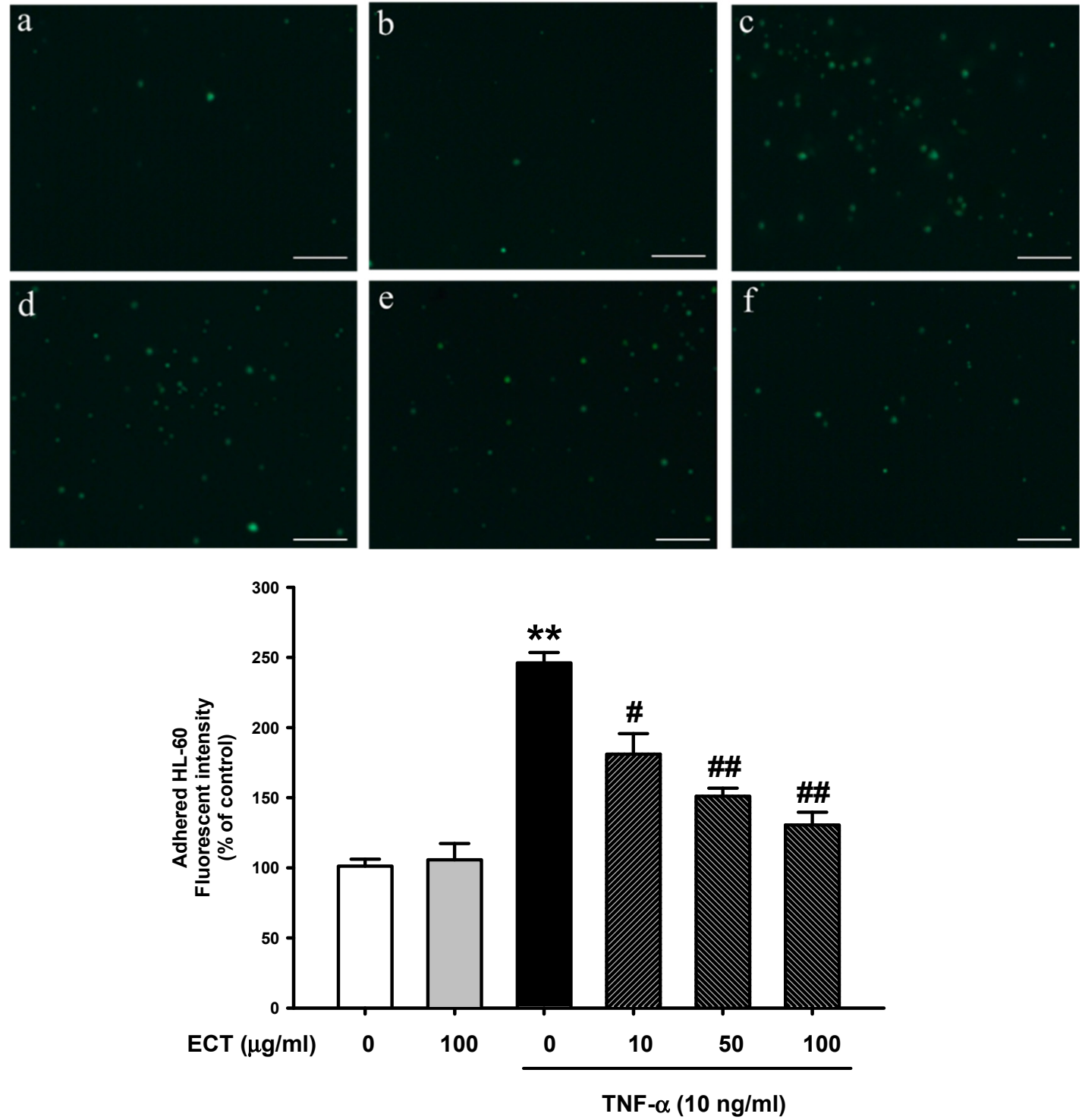

Figure 4. Effects of ECT on TNF- $\alpha$-stimulated adhesion of HL-60 to HUVEC. Fluorescence of the adhered HL-60 was captured by a fluorescent microscope $(200 \times)$ and quantified by microplate reader. Scalebars shows $100 \mu \mathrm{m}$. (a), control; (b), $100 \mu \mathrm{g} / \mathrm{mL}$ ECT; (c), TNF- $\alpha$; (d), $10 \mu \mathrm{g} / \mathrm{mL}$ ECT + TNF- $\alpha$; (e), $50 \mu \mathrm{g} / \mathrm{mL}$ ECT + TNF- $\alpha$; (f), $100 \mu \mathrm{g} / \mathrm{mL}$ ECT + TNF- $\alpha$. Bars represent the means $\pm \mathrm{SEM}$ of three independent experiments. ${ }^{* *} p<0.01$ vs. non-treated control; $\# p<0.05, \# \# p<0.01$ vs. TNF- $\alpha$.

\subsection{Effect of ECT on TNF- $\alpha$-Induced ROS/NF- $\kappa B$ Pathway}

Oxidative stress is a crucial factor of atherosclerosis pathophysiology and TNF- $\alpha$ induces ROS production in vascular tissue. HUVEC were labeled with a cell-permeable fluorescent probe, $\mathrm{CM}-\mathrm{H}_{2}$ DCFDA. As shown in Figure 5, intracellular ROS generation was markedly increased by TNF- $\alpha$ stimulation compared to untreated cell (Control). However, pretreatment with $100 \mu \mathrm{g} / \mathrm{mL}$ ECT significantly reduced ROS production by TNF- $\alpha$; its effect similarly appeared like that of ROS scavenger $N$-acetyl-L-cysteine (NAC). 

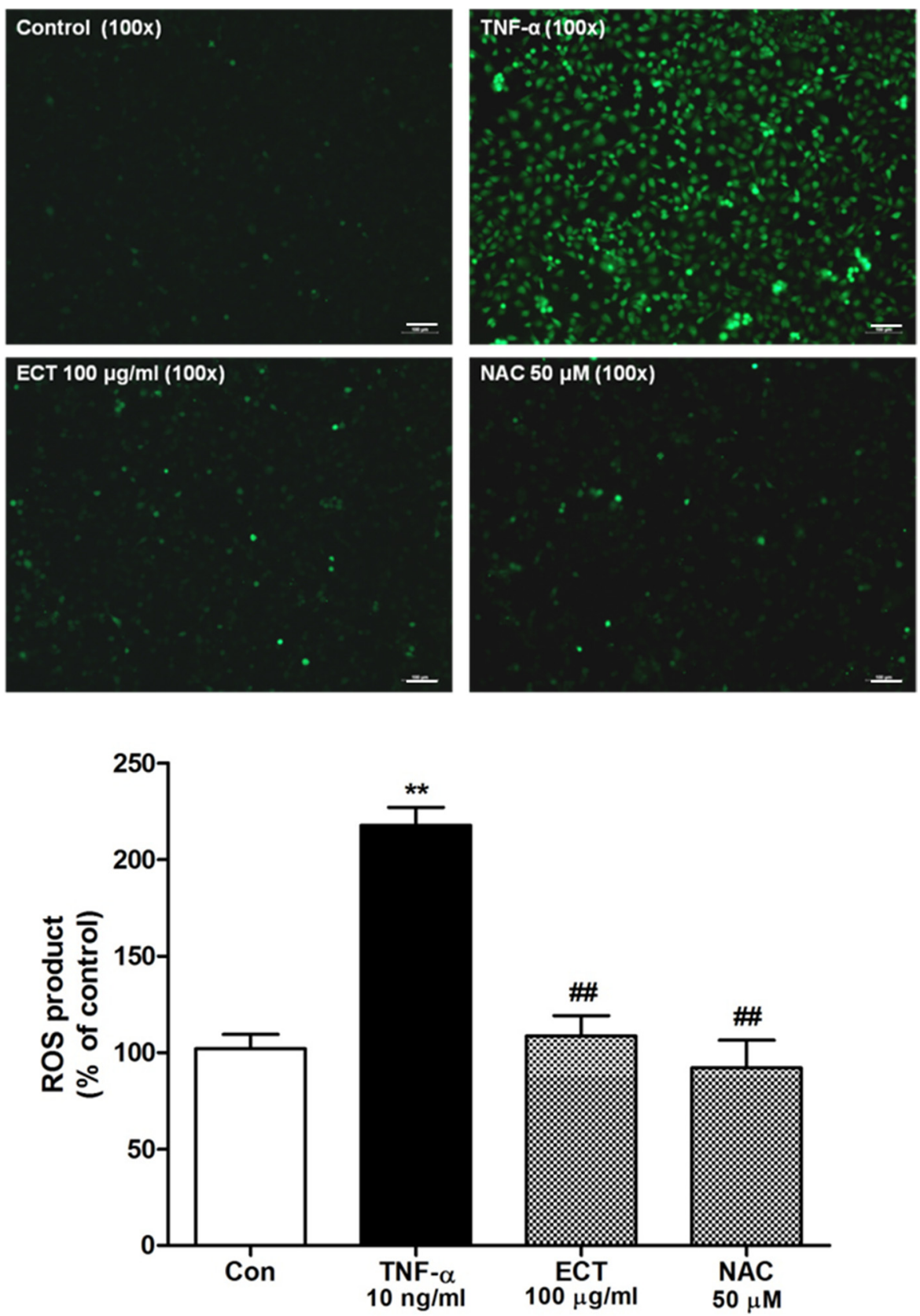

Figure 5. Effects of ECT on TNF- $\alpha$-stimulated intracellular reactive oxygen species (ROS) generation. Cells were treated with TNF- $\alpha$ with/without $100 \mu \mathrm{g} / \mathrm{mL}$ ECT and then incubated with $\mathrm{H}_{2}$ DCFDA. ROS generation was measured by a fluorescent microscope $(200 \times)$ and microplate reader. Scalebars shows $100 \mu \mathrm{m}$. The lower bars represent the means \pm SEM of more than three independent experiments. ${ }^{* *} p<0.01$ vs. non-treated control; \#\# $p<0.01$ vs. TNF- $\alpha$.

Next, p65 NF-kB translocation from the cytoplasm to the nucleus was analyzed by Western blot. After treatment with TNF- $\alpha$, the level of p65 NF-kB increased in the nucleus, while its level was decreased in the cytoplasm. ECT markedly inhibited TNF- $\alpha$-induced nuclear translocation of p65 NF- $\kappa$ B (Figure $6 \mathrm{~A}$ ). Concomitantly, ECT suppressed the NF- $\kappa \mathrm{B}$ activity that binds to DNA in TNF- $\alpha$-stimulated HUVEC (Figure $6 \mathrm{~B}, \mathrm{C}$ ). These data suggest that ECT suppress ROS/NF- $\kappa$ B pathway under TNF- $\alpha$ stimulation. 
(A)

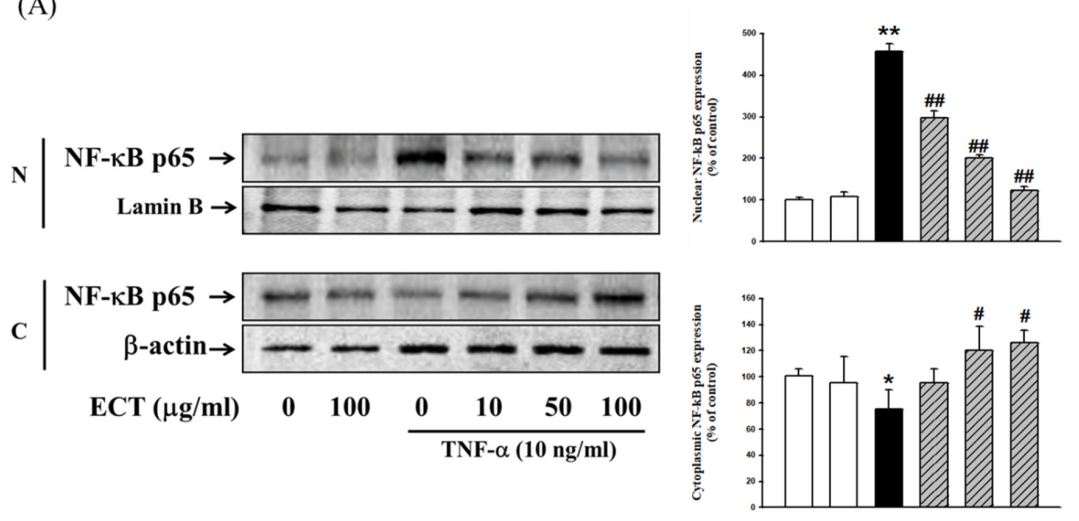

(B)

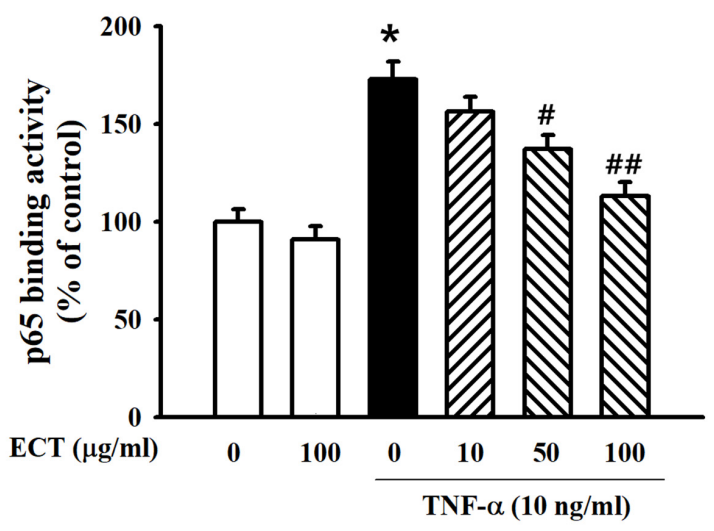

(C)
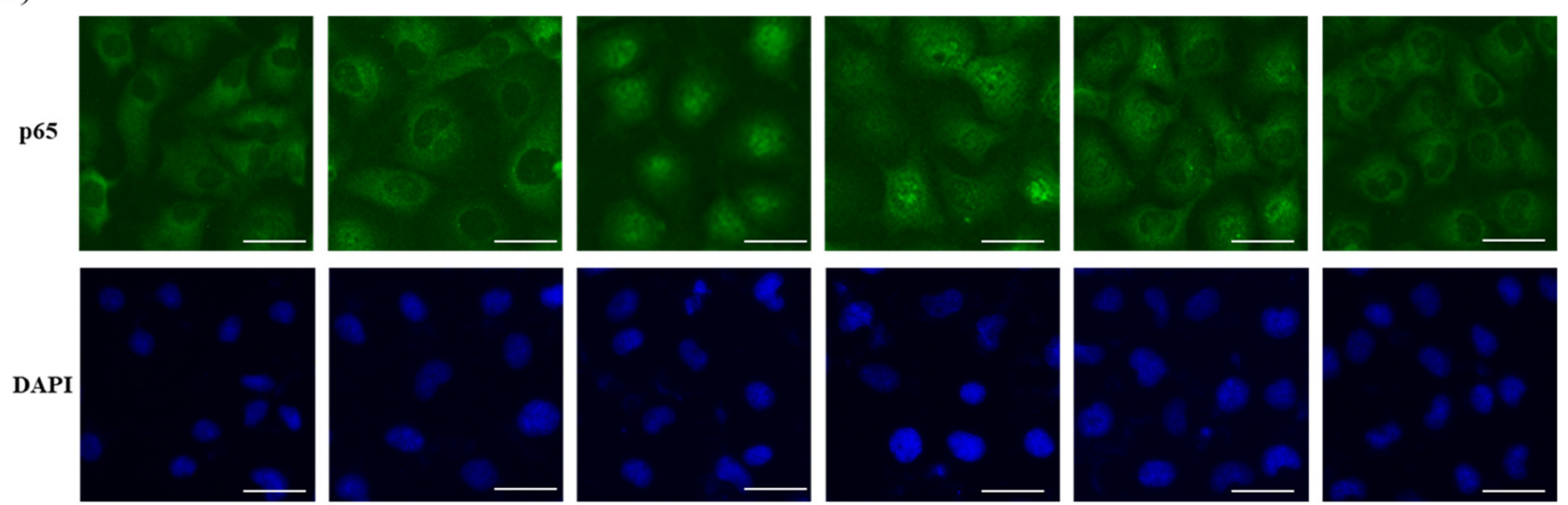

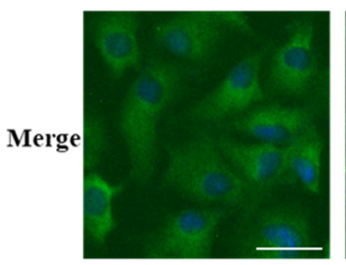

$\mathrm{ECT}(\mu \mathrm{g} / \mathrm{ml})$

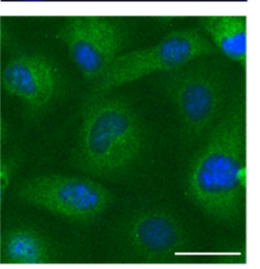

100

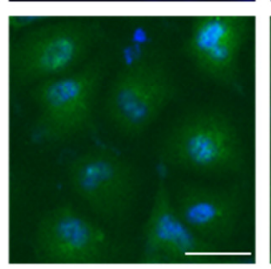

0

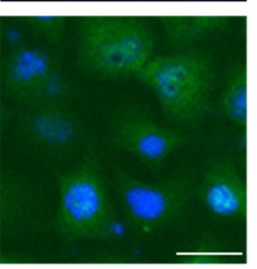

10

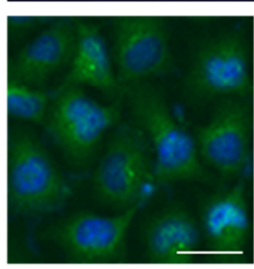

50

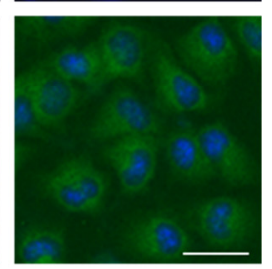

100

TNF- $\alpha(10 \mathrm{ng} / \mathrm{ml})$

Figure 6. Effects of ECT on TNF- $\alpha$-stimulated p65 NF-kB nuclear translocation. (A) Cells were pre-treated with TNF- $\alpha$ with/without 10, 50, $100 \mu \mathrm{g} / \mathrm{mL}$ ECT. Nuclear and cytosolic NF- $\mathrm{B}$ p65 protein was detected by Western blot, respectively.

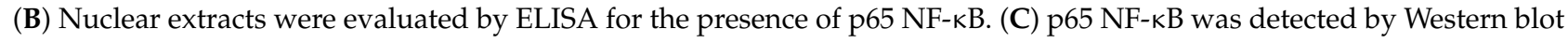
and immunofluorescence (NF- $\kappa B$, green; Nucleus, blue). Scale bars $=75 \mu \mathrm{m}$, original magnification is $400 \times$. Magnification is $400 \times$. Each bar represents the means \pm SEM of three independent experiments. ${ }^{*} p<0.05,{ }^{* *} p<0.01$ vs. non-treated control; \# $p<0.05$, \#\# $p<0.01$ vs. TNF- $\alpha$. 


\subsection{Involvement of HO-1/Nrf2 Pathway in ECT Protective Effect against Vascular Inflammation}

We examined whether ECT regulates the expression of HO-1 and Nrf2 to examine possible defense system against cytokine stimulation. ECT $(10-100 \mu \mathrm{g} / \mathrm{mL})$ upregulated HO-1 expression in a dose-dependent manner; its effect at a concentration of $100 \mu \mathrm{g} / \mathrm{mL}$ ECT similarly appeared that of HO-1 inducer CoPP. HO-1 expression was gradually increased from 4 to $12 \mathrm{~h}$ after exposure to ECT (Figure 7). Furthermore, Nrf2 expression in the nucleus was increased by ECT (Figure 8). Nuclear translocation of Nrf2 occurred $2 \mathrm{~h}$ after ECT treatment prior to HO-1 upregulation. These data indicate that ECT has a protective effect on vascular inflammation and its action is related to the activation of the HO-1/Nrf2 pathway axis.
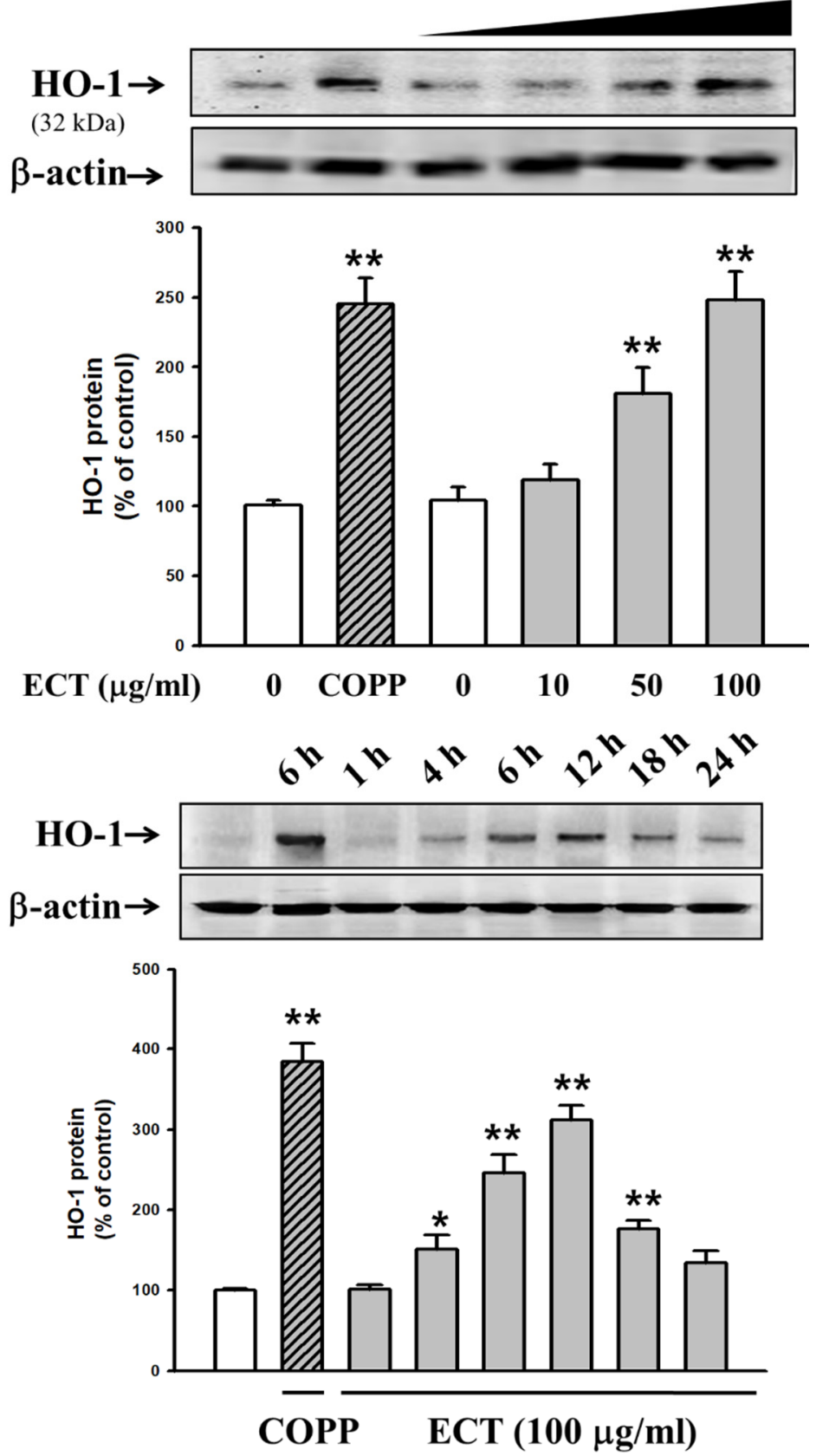

Figure 7. Effects of ECT on HO-1 induction. HUVECs were treated with $5 \mu \mathrm{M}$ COPP or ECT (dose $10-100 \mu \mathrm{g} / \mathrm{mL}$, time 1-24 h, respectively) as described in Methods. Each bar represents the means \pm SEM of three independent experiments. ${ }^{*} p<0.05,{ }^{* *} p<0.01$ vs. control group. 

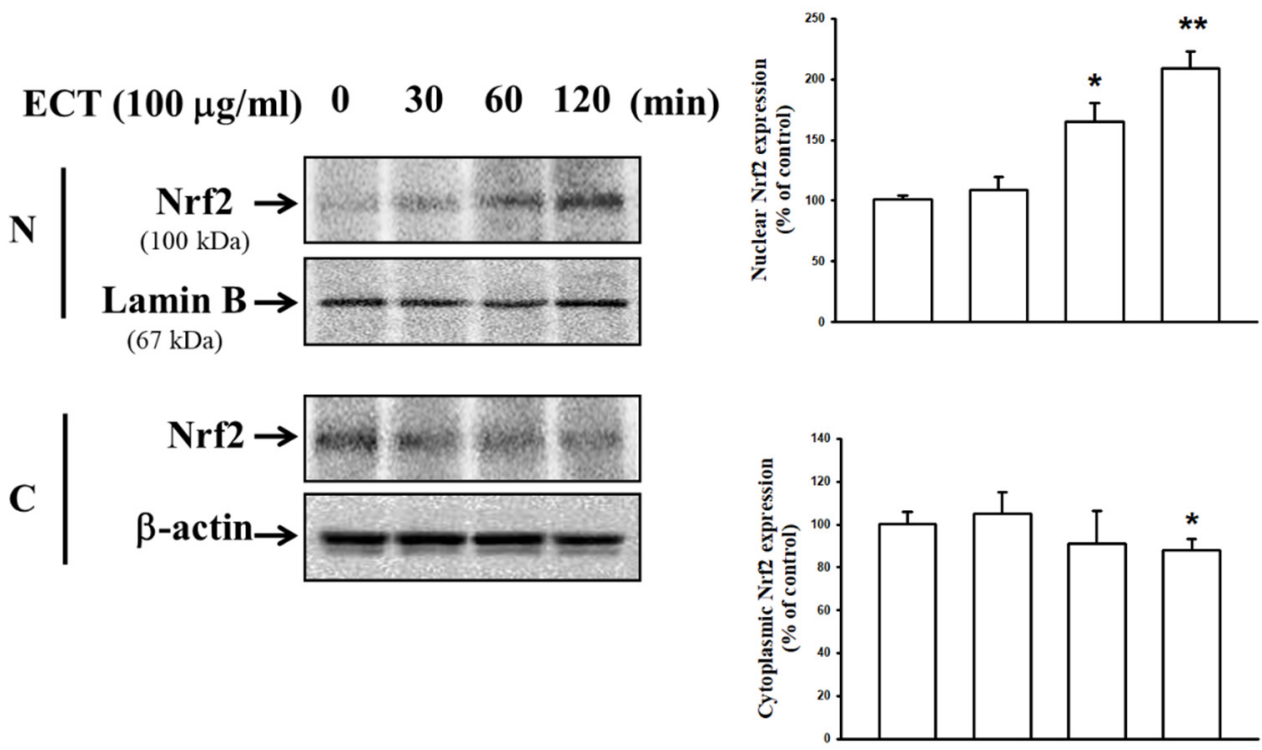

(A)

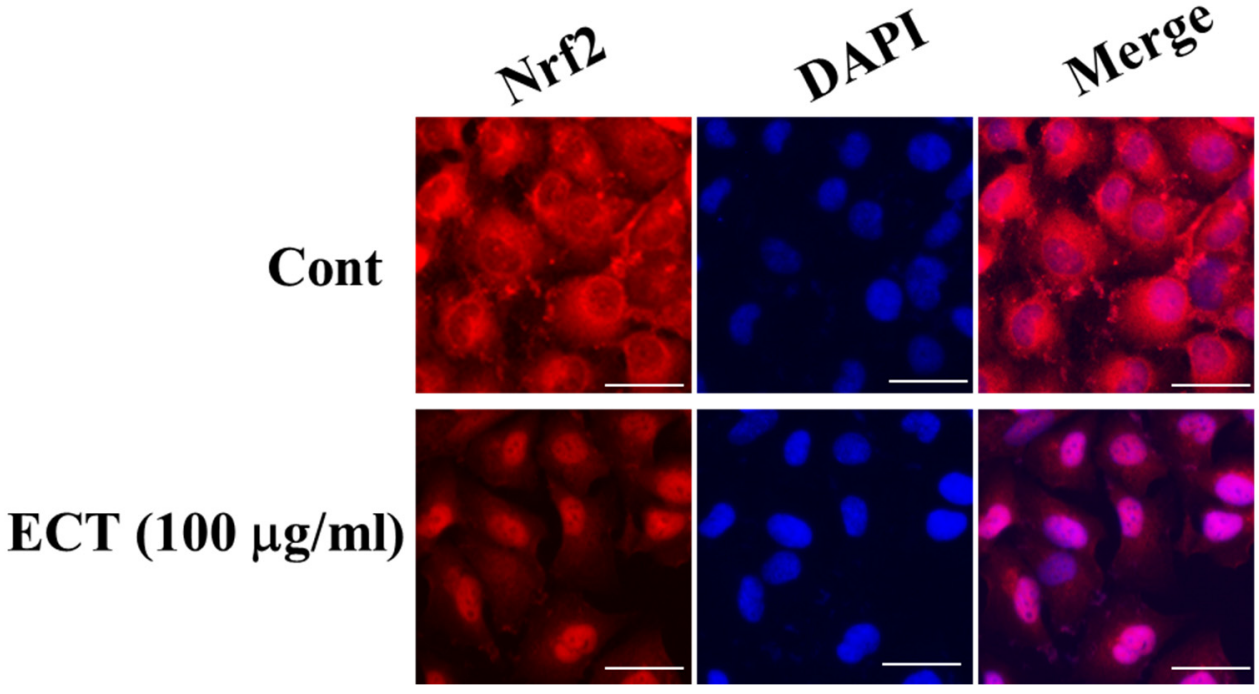

(B)

Figure 8. Effects of ECT on Nrf2 nuclear translocation. HUVECs were treated with ECT at the time point and then nuclear and cytosolic fraction were performed. Nrf-2 expression was detected by Western blotting (A). Right panel shows the densitometric analysis of Western blot. Immunofluorescence was performed as described in Methods (B). Alexa 594-Nrf-2 was detected as red and DAPI was detected as blue. Scale bars $=75 \mu \mathrm{m}$, original magnification is $400 \times$. The blots or figure are representative of three independents. ${ }^{*} p<0.05,{ }^{* *} p<0.01$ vs. control group.

\section{Discussion}

Safflower is a medicinal herb that contains a variety of essential pharmacological compounds. Previous studies have reported that its seeds or flowers have numerous components that offer benefits to human health, such as cardiovascular protection, anticoagulant, antioxidant, and hypolipidemic activities, and other metabolic advantages [21]. The present study demonstrated that the ethanol extract of safflower suppresses vascular inflammation via inhibition of the ROS/NF-kB pathway. In addition, safflower was known to regulate the $\mathrm{Nrf} 2 / \mathrm{HO}-1$ axis and exert protective effects against vascular inflammation in HUVECs.

One of the chronic consequences of endothelial dysfunction is the pathological progression to vascular disease. Vascular inflammation is a protective response of tissue that 
eliminates prolific agents or debris; it is closely related to damage recovery [22]. When endothelial cells undergo inflammatory activation by cytokines, the upregulation of CAMs stimulates the adherence of leukocytes to endothelial cells. In this study, ECT inhibited TNF- $\alpha$-induced upregulation of ICAM-1, VCAM-1, and E-selectin expression, leading to a decrease in the adhesion of HL-60 monocytes. These results suggest that ECT affects the vascular inflammation process through the inhibition of CAM expression in TNF- $\alpha-$ stimulated HUVECs.

In case of diabetic complication, advanced glycation end products (AGE)/receptor for AGE signaling promotes the production of $\mathrm{O}_{2}{ }^{-}$, which could further aggravate both the oxidative stress and the impairment of $\mathrm{NO}[23,24]$. Especially, $\mathrm{O}_{2}{ }^{-}$is a chemical precursor of many ROS such as $\mathrm{H}_{2} \mathrm{O}_{2}$, and $\mathrm{ONOO}^{-}$in vascular disease. Thus, the overproduction of $\mathrm{O}_{2}{ }^{-}$by AGE/RAGE or TNF- $\alpha$ may cause the impaired NO function [25]. TNF- $\alpha$ activates the transcription of proinflammatory gene products through a nuclear translocation of NF- $\mathrm{KB}$ and subsequent induction of the CAMs promotor genes. In addition, ROS are involved in all steps of atherosclerosis [26]. ECT treatment decreased the intracellular ROS generation and the nuclear translocation of NF- $\mathrm{kB}$. Furthermore, NF- $\mathrm{kB}-\mathrm{DNA}$ binding activity was significantly reduced by ECT treatment, suggesting that ECT suppressed vascular endothelial inflammation leading to atherosclerosis via the inhibition of ROS/NFКB pathway.

Recently, HO-1 expression has been shown to attenuate atherosclerotic processes in vascular endothelial cells, suggesting an anti-atherogenic action [13,27,28]. A human study of HO-1-deficiency showed severe endothelial damage and early atherosclerotic lesions, as reflected by the presence of plaque and fatty streaks [29]. In addition, analysis of polymorphisms in the promoter region of the human HO-1 gene substantiates the beneficial role of HO-1 against atherosclerosis [30]. In the present study, pretreatment with ECT markedly increased Nrf2/HO-1 expression, while suppressing the ROS/NF- $\mathrm{kB}$ pathway after TNF- $\alpha$ stimulation. These data demonstrate that ECT regulates the defense system against vascular inflammation, leading to atherosclerosis. Under normal conditions, Nrf2 activity is suppressed in the cytosol by specific binding to the Keap1 chaperone [31].

Electrophilic agents or stimulatory compounds lead to modify thiol groups and then Keap1-mediated repression of Nrf2 activity is lost, then induces Nrf2 nuclear translocation and the potentiation of the ARE response [32]. Finally, this Nrf2/HO-1 induction generate the antioxidant biliverdin and the signaling molecule $\mathrm{CO}$. It is well known that $\mathrm{Nrf} 2 / \mathrm{HO}-1 / \mathrm{CO}$ signaling axis shows protective roles in any type of vascular defense system, and therefore, it might be a potential and useful target as a therapeutic resource for cardiovascular disease.

Drugs that are clinically used to treat cardiovascular diseases should be carefully studied because most of the HO-1 inducers such as hemin or tin compounds have limitations resulting from their cellular toxicity or nephrotoxicity, despite their capabilities [33]. Here, we provide valuable data that ECT shows no cytotoxicity, but only decreases inflammation in vascular endothelial cells.

\section{Conclusions}

In this report, Carthamus tinctorius has been shown to have protective effects against vascular inflammation in cytokine-stimulated HUVEC. Carthamus tinctorius significantly inhibited expression of cell adhesion molecule, early atherosclerosis marker, via attenuating the ROS/NF-kB pathway. Here, the regulation of Nrf-2/HO-1/CO signaling axis is involved in vascular protection (Figure 9). Therefore, further in vivo studies are required to clarify the therapeutic potential role of Carthamus tinctorius to protect vascular disease. In addition, further study will be needed to clarify which compound is dominant for protection of vascular diseases. 


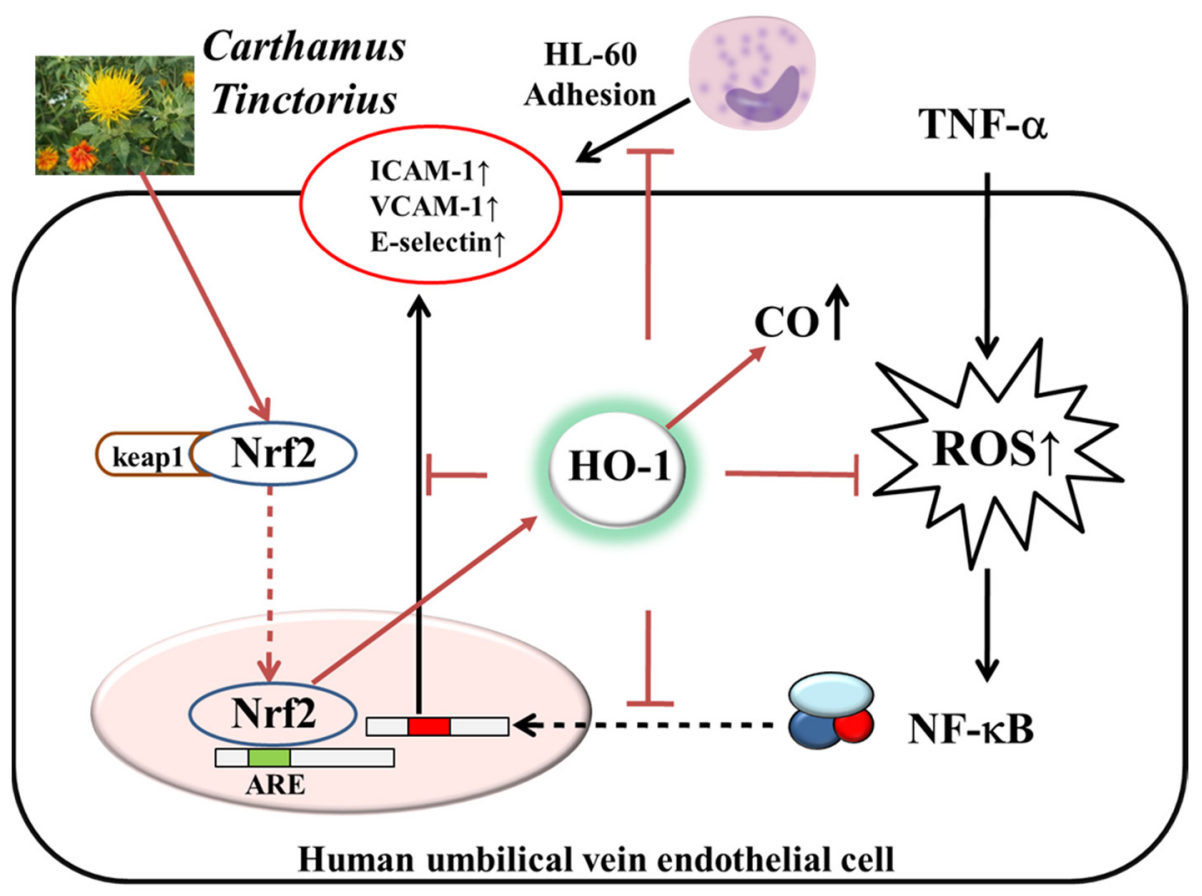

Figure 9. Schematic diagram of the effects of flowers of $C$. tinctorius in vascular inflammation of HUVEC. The potential role of flowers of $C$. tinctorius as a beneficial therapeutic herb inhibited vascular inflammation via ROS/NF-kB pathway. However, modulation of Nrf-2/HO-1/CO signaling axis is involved in its vascular protection in vascular endothelial cells.

Author Contributions: Y.J.L. designed the experiments; Y.P.L., E.S.C., B.H.H., C.S.S. and J.J.Y. performed the experiments; S.H.J., C.G.J. and Y.J.M. analyzed the data; Y.J.L., D.G.K. and H.S.L. wrote the manuscript. All authors have read and agreed to the published version of the manuscript.

Funding: This study was supported by a National Research Foundation of Korea (NRF) Grant funded by the Korean government (MSIP) [No. 2017R1A5A2015805, 2019R1A2C1085650, 2021R1A2C1010859].

Institutional Review Board Statement: The study was conducted according to the guidelines of the Declaration of Helsinki, and approved by the Institutional Review Board of Wonkwang University (WKIRB-202112-BR-105).

Informed Consent Statement: Not applicable.

Data Availability Statement: The data used to support the findings of this study are included within the article.

Conflicts of Interest: The authors declare that they have no conflict of interest.

\section{References}

1. Kim, H.; Kim, S.; Han, S.; Rane, P.P.; Fox, K.M.; Qian, Y.; Suh, H.S. Prevalence and incidence of atherosclerotic cardiovascular disease and its risk factors in Korea: A nationwide population-based study. BMC Public Health. 2019, 19, 1112. [CrossRef] [PubMed]

2. Fatkhullina, A.R.; Peshkova, I.O.; Koltsova, E.K. The Role of Cytokines in the Development of Atherosclerosis. Biochemistry 2016, 81, 1358-1370. [CrossRef] [PubMed]

3. Yang, J.; Zhang, L.; Yu, C.; Yang, X.F.; Wang, H. Monocyte and macrophage differentiation: Circulation inflammatory monocyte as biomarker for inflammatory diseases. Biomark. Res. 2014, 2, 1. [CrossRef] [PubMed]

4. Rafieian-Kopaei, M.; Setorki, M.; Doudi, M.; Baradaran, A.; Nasri, H. Atherosclerosis: Process, indicators, risk factors and new hopes. Int. J. Prev. Med. 2014, 5, 927-946.

5. Li, S.; Lu, J.; Chen, Y.; Xiong, N.; Li, L.; Zhang, J.; Yang, H.; Wu, C.; Zeng, H.; Liu, Y. MCP-1-induced ERK/GSK-3ß/Snail signaling facilitates the epithelial-mesenchymal transition and promotes the migration of MCF-7 human breast carcinoma cells. Cell. Mol. Immunol. 2017, 14, 621-630. [CrossRef] 
6. He, L.; He, T.; Farrar, S.; Ji, L.; Liu, T.; Ma, X. Antioxidants Maintain Cellular Redox Homeostasis by Elimination of Reactive Oxygen Species. Cell. Physiol. Biochem. 2017, 44, 532-553. [CrossRef]

7. Madamanchi, N.R.; Runge, M.S. Redox signaling in cardiovascular health and disease. Free Radic. Biol. Med. 2013, 61, 473-501. [CrossRef]

8. Javan, H.; Szucsik, A.M.; Li, L.; Schaaf, C.L.; Salama, M.E.; Selzman, C.H. Cardiomyocyte p65 nuclear factor-kB is necessary for compensatory adaptation to pressure overload. Circ. Heart Fail. 2015, 8, 109-118. [CrossRef]

9. Jarmi, T.; Agarwal, A. Heme oxygenase and renal disease. Curr. Hypertens. Rep. 2009, 11, 56-62. [CrossRef]

10. Origassa, C.S.; Câmara, N.O. Cytoprotective role of heme oxygenase-1 and heme degradation derived end products in liver injury. World J. Hepatol. 2013, 5, 541-549. [CrossRef]

11. Abraham, N.G.; Cao, J.; Sacerdoti, D.; Li, X.; Drummond, G. Heme oxygenase: The key to renal function regulation. Am. J. Physiol. Renal. Physiol. 2009, 297, F1137-F1152. [CrossRef] [PubMed]

12. Luo, Y.; Sun, G.; Dong, X.; Wang, M.; Qin, M.; Yu, Y.; Sun, X. Isorhamnetin attenuates atherosclerosis by inhibiting macrophage apoptosis via PI3K/AKT activation and HO-1 induction. PLoS ONE 2015, 10, e0120259. [CrossRef] [PubMed]

13. Liu, Z.; Wang, J.; Huang, E.; Gao, S.; Li, H.; Lu, J.; Tian, K.; Little, P.J.; Shen, X.; Xu, S.; et al. Tanshinone IIA suppresses cholesterol accumulation in human macrophages: Role of heme oxygenase-1. J. Lipid Res. 2014, 55, 201-213. [CrossRef]

14. Chen, M.; Yan, X.T.; Ye, L.; Tang, J.J.; Zhang, Z.Z.; He, X.H. Dexmedetomidine Ameliorates Lung Injury Induced by Intestinal Ischemia/Reperfusion by Upregulating Cannabinoid Receptor 2, Followed by the Activation of the Phosphatidylinositol 3Kinase/Akt Pathway. Oxid. Med. Cell. Longev. 2020, 2020, 6120194. [CrossRef]

15. Shopit, A.; Niu, M.; Wang, H.; Tang, Z.; Li, X.; Tesfaldet, T.; Ai, J.; Ahmad, N.; Al-Azab, M.; Tang, Z. Protection of diabetes-induced kidney injury by phosphocreatine via the regulation of ERK/Nrf2/HO-1 signaling pathway. Life Sci. 2020, 242, 117248. [CrossRef]

16. Che, C.T.; Wong, M.S.; Lam, C.W. Natural Products from Chinese Medicines with Potential Benefits to Bone Health. Molecules 2016, 21, 239. [CrossRef]

17. Delshad, E.; Yousefi, M.; Sasannezhad, P.; Rakhshandeh, H.; Ayati, Z. Medical uses of Carthamus tinctorius L. (Safflower): A comprehensive review from Traditional Medicine to Modern Medicine. Electron. Physician. 2018, 10, 6672-6681. [CrossRef]

18. Zhou, X.; Tang, L.; Xu, Y.; Zhou, G.; Wang, Z. Towards a better understanding of medicinal uses of Carthamus tinctorius L. in traditional Chinese medicine: A phytochemical and pharmacological review. J. Ethnopharmacol. 2014, 151, 27-43. [CrossRef]

19. Zhou, F.R.; Zhao, M.B.; Tu, P.F. Simultaneous determination of four nucleosides in Carthamus tinctorius L. and Safflower injection using highperformance liquid chromatography. J. Chin. Pharm. Sci. 2009, 18, 326-330.

20. Kim, D.H.; Lee, S.M.; Lee, Y.J.; Yoon, J.J.; Tan, R.; Yu, Y.C.; Kang, D.G.; Lee, H.S. Effect of Paeotang on tumor necrosis factor $\alpha$-induced vascular inflammation in human umbilical vein endothelial cells. Chin. J. Integr. Med. 2017, 24, 1-10. [CrossRef]

21. Mani, V.; Lee, S.K.; Yeo, Y.; Hahn, B.S. A Metabolic Perspective and Opportunities in Pharmacologically Important Safflower. Metabolites 2020, 10, 253. [CrossRef] [PubMed]

22. Zhang, C. The role of inflammatory cytokines in endothelial dysfunction. Basic Res. Cardiol. 2008, 103, 398-406. [CrossRef]

23. Nowotny, K.; Jung, T.; Höhn, A.; Weber, D.; Grune, T. Advanced glycation end products and oxidative stress in type 2 diabetes mellitus. Biomolecules 2015, 5, 194-222. [CrossRef]

24. Goldfine, A.B.; Shoelson, S.E. Therapeutic approaches targeting inflammation for diabetes and associated cardiovascular risk. J. Clin. Investig. 2017, 127, 83-93. [CrossRef] [PubMed]

25. Di Meo, S.; Reed, T.T.; Venditti, P.; Victor, V.M. Role of ROS and RNS Sources in Physiological and Pathological Conditions. Oxid. Med. Cell. Longev. 2016, 2016, 1245049. [CrossRef] [PubMed]

26. Gáll, T.; Balla, G.; Balla, J. Heme, Heme Oxygenase, and Endoplasmic Reticulum Stress-A New Insight into the Pathophysiology of Vascular Diseases. Int. J. Mol. Sci. 2019, 20, 3675. [CrossRef]

27. Schumacher, A.; Zenclussen, A.C. Effects of heme oxygenase-1 on innate and adaptive immune responses promoting pregnancy success and allograft tolerance. Front. Pharmacol. 2015, 5, 288. [CrossRef]

28. Durante, W. Targeting Heme Oxygenase-1 in the Arterial Response to Injury and Disease. Antioxidants 2020, 9, 829. [CrossRef]

29. Ho, Y.C.; Wu, M.L.; Gung, P.Y.; Chen, C.H.; Kuo, C.C.; Yet, S.F. Heme oxygenase-1 deficiency exacerbates angiotensin II-induced aortic aneurysm in mice. Oncotarget 2016, 7, 67760-67776. [CrossRef] [PubMed]

30. Guo, N.; Zhang, N.; Yan, L.; Cao, X.; Wang, J.; Wang, Y. Correlation between genetic polymorphisms within the MAPK1/HIF1/HO-1 signaling pathway and risk or prognosis of perimenopausal coronary artery disease. Clin. Cardiol. 2017, 40, 597-604. [CrossRef]

31. Villeneuve, N.F.; Lau, A.; Zhang, D.D. Regulation of the Nrf2-Keap1 antioxidant response by the ubiquitin proteasome system: An insight into cullin-ring ubiquitin ligases. Antioxid. Redox Signal. 2010, 13, 1699-1712. [CrossRef] [PubMed]

32. He, X.; Ma, Q. NRF2 cysteine residues are critical for oxidant/electrophile-sensing, Kelch-like ECH-associated protein-1dependent ubiquitination-proteasomal degradation, and transcription activation. Mol. Pharmacol. 2009, 76, 1265-1278. [CrossRef] [PubMed]

33. Kim, Y.M.; Pae, H.O.; Park, J.E.; Lee, Y.C.; Woo, J.M.; Kim, N.H.; Choi, Y.K.; Lee, B.S.; Kim, S.R.; Chung, H.T. Heme oxygenase in the regulation of vascular biology: From molecular mechanisms to therapeutic opportunities. Antioxid. Redox Signal. 2011, 14, 137-167. [CrossRef] [PubMed] 